\title{
Analisis Kestabilan dan Kontrol Optimal Model Matematika Partisipasi Pemilih pada Pemilihan Umum dengan Saturated Incidence Rate
}

\author{
Dinda Ariska Putri ${ }^{1}$, Windarto ${ }^{1, *} \&$ Cicik Alfiniyah ${ }^{1}$ \\ ${ }^{1}$ Departemen Matematika, Fakultas Sains dan Teknologi, Universitas Airlangga, Indonesia
}

*Corresponding author : windarto@fst.unair.ac.id

\begin{abstract}
Voter participation in general elections is an important aspect of a democratic state structure. Participation is determined by the level of public political awareness, if the level of public political awareness is low, voter participation tends to be passive (Abstinence). A mathematical model approach to voter participation in elections that has been modified to a saturated incidence rate is needed to predict voter participation in future elections. This thesis aims to analyze the stability of the equilibrium point and apply the optimal control variable in the form of an awareness campaign. In the model without control variables, we obtain two equilibriums, namely, the nonendemic equilibrium and the endemic equilibrium. Local stability and the existence of endemic equilibrium depend on the basic reproduction number $\left(R_{0}\right)$, where $R_{0}=\beta \Lambda /(\gamma+\mu) \mu$. There is voter participation in elections when $\mathrm{R}_{0}<1$ and the absence of voter participation in elections when $\mathrm{R}_{0}>$ 1. We also analyze the sensitivity of parameters to determine which parameters are the most influential in this mathematical model. Furthermore, the application of control variables in the mathematical model of voter participation in elections with saturated incidence rate is determined through the Pontryagin Maximum Principle method. Numerical simulation results show that providing control variables in the form of awareness campaign it is quite effective in minimize the number of the voting population who abstained from election.
\end{abstract}

Keywords: Mathematical Models, Optimal Control, Saturated Incidence Rate, Stability, Voter Participation.

\section{Pendahuluan}

Partisipasi politik masyarakat merupakan aspek penting dalam sebuah tatanan negara demokrasi. Setiap masyarakat memiliki hak untuk menentukan pilihan mereka dalam pemilihan umum [1]. Pemilihan umum berperan sebagai mekanisme perubahan politik mengenai pola dan arah kebijakan publik atau mengenai sirkulasi elit secara periodik dan tertib [2].

Berdasarkan Undang Undang Nomor 7 Tahun 2017 dalam pelaksanaannya, pemilihan umum di Indonesia bertujuan untuk memilih anggota legislatif, yaitu Dewan Perwakilan Rakyat, anggota Dewan Perwakilan Daerah, Presiden dan Wakil Presiden, dan untuk 
memilih anggota Dewan Perwakilan Rakyat Daerah. Pemilihan umum diselenggarakan dengan asas langsung, umum, bebas, rahasia, jujur, dan adil dalam Negara Kesatuan Republik Indonesia Tahun 1945 [3].

Partisipasi politik adalah keikutsertaan warga negara biasa dalam menentukan segala keputusan yang menyangkut atau mempengaruhi hidupnya [4]. Tingginya partisipasi politik masyarakat menunjukkan bahwa rakyat mengikuti dan memahami masalah politik dan bersedia melibatkan diri dalam kegiatan-kegiatan tersebut. Sebaliknya, apabila tingkat partisipasi politik masyarakat rendah menunjukkan bahwa rakyat tidak menaruh perhatian terhadap masalah kenegaraan dan ketidakpercayaan rakyat pada proses politik $[5]$.

Partisipasi ditentukan oleh tingkat kesadaran politik dan kepercayaan masyarakat terhadap pemerintah. Apabila seseorang memiliki kesadaran politik dan tingkat kepercayaan kepada pemerintah tinggi maka partisipasi politik cenderung aktif. Sebaliknya apabila kesadaran politik dan tingkat kepercayaan kepada pemerintah rendah maka partisipasi politik cenderung pasif-tertekan (Golput) [6].

Pemodelan matematika mengenai dinamika partisipasi pemilih telah banyak dilakukan. Model matematika partisipasi pemilih dengan interaksi antara pemilih dan partai politik [7]. Selain itu, melakukan estimasi parameter terhadap data pemilih [8-9]. Selanjutnya, terdapat model yang menyajikan interaksi antara partai politik [10-11].

Berdasarkan uraian di atas, penulis akan mengkaji model matematika partisipasi pemilih pada pemilihan umum dengan saturated incidence rate yang merujuk pada jurnal yang dikembangkan oleh Balatif dkk [12]. Oleh karena itu, dalam artikel ini akan dibahas modifikasi model Balatif dkk tersebut dengan memperhatikan saturated incidence rate dan menambahkan variabel kontrol optimal berupa kampanye kesadaran.

\section{Formulasi Model}

Pada bagian ini akan diformulasikan model matematika partisipasi pemilih pada pemilihan umum dengan saturated incidence rate. Model tersebut terdiri atas tiga variabel yaitu populasi pemilih yang berhak berpartisipasi dalam pemilihan umum namun berpotensi golput $(P)$, populasi pemilih yang golput pada pemilihan umum $(A)$, populasi pemilih yang terdaftar dan menggunakan hak pilih $(R)$. Adapun asumsi yang digunakan untuk kontruksi model sebagai berikut.

1. Individu masuk ke dalam populasi pemilih ketika sudah berumur 17 tahun keatas.

2. Pemilih yang berhak memilih namun berpotensi golput $(P)$ bisa menjadi golput karena adanya pengaruh dari pemilih yang golput $(A)$.

3. Pemilih yang berhak memilih namun berpotensi golput $(P)$ akan mantap menggunakan hak pilihnya karena adanya pengaruh dari pemilih yang terdaftar dan menggunakan hak pilihnya $(R)$. 
Deskripsi parameter-parameter yang akan digunakan dalam model matematika partisipasi pemilih pada pemilihan umum dengan saturated incidence rate disajikan pada Tabel 1.

Tabel 1 Pendefinisian parameter model

\begin{tabular}{|c|c|}
\hline Notasi & Keterangan \\
\hline$\Lambda$ & $\begin{array}{l}\text { Laju masuk individu baru di dalam sistem } \\
\text { pemilu }\end{array}$ \\
\hline$\beta$ & $\begin{array}{l}\text { Laju individu yang terpengaruh untuk } \\
\text { golput }\end{array}$ \\
\hline$\eta$ & $\begin{array}{l}\text { Laju individu yang mantap menggunakan } \\
\text { hak pilihnya }\end{array}$ \\
\hline$\gamma$ & $\begin{array}{l}\text { Laju individu kehilangan minat untuk } \\
\text { golput }\end{array}$ \\
\hline
\end{tabular}

Berdasarkan asumsi-asumsi dan pendefinisian variabel yang telah dijelaskan sebelumnya, diagram transmisi model matematika partisipasi pemilih pada pemilihan umum dengan saturated incidence rate disajikan dalam Gambar 1 berikut ini.

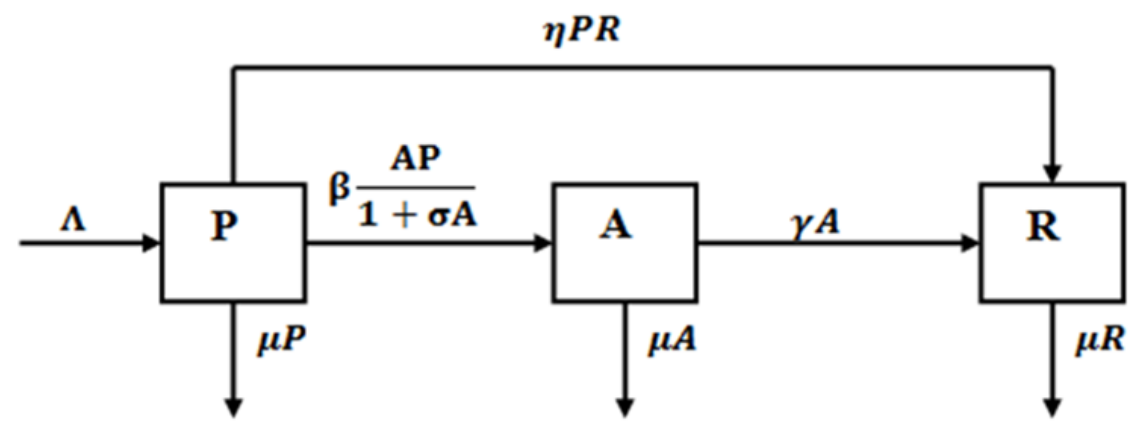

Gambar 1 Diagram transmisi model

Berdasarkan diagram transmisi pada Gambar 1, maka model matematika partisipasi pemilih pada pemilihan umum dengan saturated incidence rate dapat dituliskan sebagai berikut.

$$
\begin{aligned}
& \frac{d P}{d t}=\Lambda-\beta \frac{A P}{1+\sigma A}-\eta P R-\mu P, \\
& \frac{d A}{d t}=\beta \frac{A P}{1+\sigma A}-(\gamma+\mu) A, \\
& \frac{d R}{d t}=\eta P R+\gamma A-\mu R .
\end{aligned}
$$


Persamaan (1) menunjukkan laju perubahan populasi pemilih yang berhak memilih namun berpotensi golput per satuan waktu. Terdapat pertambahan populasi akibat laju masuk individu baru di dalam sistem pemilu dan berkurang karena adanya interaksi dengan populasi pemilih yang terdaftar dan menggunakan hak pilih sehingga pemilih mantap menggunakan hak pilihnya. Meskipun demikian, populasi pemilih yang berhak memilih namun berpotensi golput berkurang adanya interaksi dengan populasi pemilih yang golput dari pemilihan umum. Selain itu, populasi dapat berkurang akibat adanya kematian alami pada populasi pemilih yang berhak memilih namun berpotensi golput.

Persamaan (2) menyatakan laju perubahan populasi pemilh yang golput pada pemilihan umum terhadap waktu. Populasi ini bertambah ketika individu dalam populasi pemilih yang berhak memilih namun berpotensi golput berinteraksi dengan populasi pemilih yang golput dari pemilihan umum. Selain itu, populasi dapat berkurang karena adanya interaksi dengan populasi pemilih yang terdaftar dan menggunakan hak pilih dan adanya kematian alami pada populasi pemilih yang golput pada pemilihan umum.

Persamaan (3) menyatakan laju perubahan populasi pemilih yang terdaftar dan menggunakan hak pilih terhadap waktu. Populasi ini bertambah ketika individu dalam populasi pemilih yang berhak memilih namun berpotensi golput berinteraksi dengan populasi pemilih yang terdaftar dan menggunakan hak pilih. Populasi pemilih yang terdaftar dan menggunakan hak pilih juga bertambah karena individu dalam populasi yang golput dalam pemilihan umum mulai sadar dan menggunakan hak pilihnya untuk berpartisipasi dalam pemilihan umum. Selain itu, populasi ini berkurang karena adanya kematian alami pada populasi pemilih yang terdaftar dan menggunakan hak pilih.

\section{$3 \quad$ Analisis Kestabilan Titik Setimbang}

Sebelum dilakukan uji kestabilan titik setimbang, akan ditentukan terlebih dahulu titik setimbang dengan syarat eksistensinya dan bilangan reproduksi dasar. Berdasarkan persamaan (1) - (3) didapatkan dua titik setimbang yaitu titik setimbang non pemilih golput (non endemik) dan titik setimbang adanya pemilih golput (endemik).

Titik setimbang non pemilih golput merupakan suatu keadaan ketika populasi pemilih yang golput dan populasi pemilih yang menggunakan hak pilih bernilai nol $(A=R=0)$. Misalkan titik setimbang non pemilih golput ini dapat dinyatakan dalam $E_{0}=(P, A, R)$. Dengan mensubstitusikan $A=R=0$ ke dalam persamaan (1) - (3) sehingga dapat diperoleh titik setimbang non pemilih golput $E_{0}(P, A, R)=\left(\frac{\Lambda}{\mu}, 0,0\right)$.

Selanjutnya, akan ditentukan nilai dari bilangan reproduksi dasar $\left(R_{0}\right)$ yang dapat digunakan untuk mengetahui ambang batas suatu keadaan yang menunjukkan bahwa partisipasi pemilih akan berpengaruh atau tidak dalam pemilihan umum. Metode yang 
digunakan dalam menentukan $R_{0}$ yaitu dengan menggunakan metode Next Generation Matrix (NGM) diperoleh sebagai berikut.

$$
R_{0}=\frac{\beta \Lambda}{(\gamma+\mu) \mu}
$$

Titik setimbang adaya pemilih golput merupakan suatu keadaan ketika terdapat populasi pemilih yang berhak memilih namun berpotensi golput, adanya populasi golput, dan adanya populasi yang menggunakan hak pilih $(P \neq 0, A \neq 0, R \neq 0)$. Misalkan titik setimbang adanya pemilih golput dinyatakan sebagai $E_{1}=\left(P^{*}, A^{*}, R^{*}\right)$. Dengan demikian, diperoleh titik setimbang adanya pemilih golput sebagai berikut:

$P^{*}=\frac{\Lambda \sigma+\gamma+\mu}{\beta+\eta \sigma R^{*}+\mu \sigma}$,

$A^{*}=-\frac{\left(-\beta \Lambda+\gamma \eta R^{*}+\gamma \mu+\mu \eta R^{*}+\mu^{2}\right)}{\left(\beta+\eta \sigma R^{*}+\mu \sigma\right)(\gamma+\mu)}$,

$R^{*}$ merupakan akar positif dari persamaan

$a R^{* 2}+b R^{*}+c=0$

dengan,

$a=\mu \eta \sigma \gamma+\mu^{2} \eta \sigma$

$b=\eta \Lambda \sigma \gamma+\eta \Lambda \sigma \mu+\eta \mu \gamma+\eta \mu^{2}+\mu \beta \gamma+\mu^{2} \sigma \gamma+\mu^{2} \beta+\mu^{3} \sigma$,

$c=\gamma \beta \Lambda-\gamma^{2} \mu-\gamma \mu^{2}$

Berdasarkan titik setimbang adanya pemilih golput pada pemilihan umum $E_{1}$ akan eksis jika $R^{*}>0$. Persamaan (6) akan memiliki satu akar positif jika memenuhi kondisi $\frac{c}{a}<0$. Karena semua parameter bernilai positif, maka $a>0$ sehingga diperoleh $c<0$ merupakan syarat eksistensi titik setimbang $E_{1}$. Akibatnya,

$$
\begin{gathered}
\Leftrightarrow \gamma \beta \Lambda-\gamma^{2} \mu-\gamma \mu^{2}<0 \\
\gamma^{2} \mu+\gamma \mu^{2}<\gamma \beta \Lambda \\
(\gamma+\mu) \mu<\beta \Lambda
\end{gathered}
$$

Sehingga,

$\frac{\beta \Lambda}{(\gamma+\mu) \mu}>1$

Dengan demikian titik setimbang adanya pemilih golput $E_{1}$ akan eksis jika memenuhi syarat $R_{0}>1$.

Setelah diperoleh titik setimbang, akan dilakukan analisis kestabilan terhadap kedua titik setimbang. Model matematika partisipasi pemilih pada pemilihan umum dengan saturated incidence rate berbentuk sistem dinamik non linier sehingga perlu dilakukan 
linierisasi menggunakan matriks Jacobian. Matriks Jacobian dari model matematika partisipasi pemilih pada pemilihan umum dengan saturated incidence rate adalah sebagai berikut.

$$
J=\left[\begin{array}{ccc}
-\frac{\beta A}{1+\sigma A}-\eta R-\mu & -\frac{\beta P}{1+\sigma A}+\frac{\beta \sigma P A}{(1+\sigma A)^{2}} & -\eta P \\
\frac{\beta A}{1+\sigma A} & \frac{\beta P}{1+\sigma A}-\frac{\beta \sigma P A}{(1+\sigma A)^{2}}-(\gamma+\mu) & 0 \\
\eta R & \gamma & \eta P-\mu
\end{array}\right],
$$

Selanjutnya, untuk melakukan analisis kestabilan titik setimbang non pemilih golput, akan disubtitusikan titik setimbang non pemilih golput $E_{0}$ pada matriks Jacobian (7) sehingga diperoleh sebagai berikut.

$$
J\left(E_{0}\right)=\left[\begin{array}{ccc}
-\mu & -\frac{\beta \Lambda}{\mu} & -\frac{\eta \Lambda}{\mu} \\
0 & \frac{\beta \Lambda}{\mu}-(\gamma+\mu) & 0 \\
0 & \gamma & \frac{\eta \Lambda}{\mu}-\mu
\end{array}\right],
$$

Akibatnya, diperoleh persamaan karakteristik sebagai berikut:

$$
(\lambda+\mu)\left(\lambda-\frac{\beta \Lambda}{\mu}+(\gamma+\mu)\right)\left(\lambda-\frac{\eta \Lambda}{\mu}+\mu\right)=0,
$$

Berdasarkan persamaan karakteristik (9) diperoleh nilai eigen sebagai berikut.

$\lambda_{1}=-\mu$

$\lambda_{2}=\frac{\beta \Lambda}{\mu}-(\gamma+\mu)$, dengan syarat $\frac{\beta \Lambda}{(\gamma+\mu) \mu}<1$ atau $R_{0}=\frac{\beta \Lambda}{(\gamma+\mu) \mu}<1$

$\lambda_{3}=\frac{\eta \Lambda}{\mu}-\mu$, dengan syarat $\eta \Lambda<\mu^{2}$

Titik setimbang non pemilih golput $E_{0}$ stabil asimtotis jika hanya jika persamaan karakteristik mempunyai akar negatif. Karena semua parameter bernilai positif maka jelas bahwa nilai eigen $\lambda_{1}$ bernilai negatif. Sedangkan syarat agar nilai eigen $\lambda_{2}<0$ terpenuhi jika $R_{0}=\frac{\beta \Lambda}{(\gamma+\mu) \mu}<1$ dan $\lambda_{3}<0$ terpenuhi jika $\eta \Lambda<\mu^{2}$. Dengan demikian titik setimbang $E_{0}$ stabil asimtotis bersyarat.

Selanjutnya, untuk melakukan analisis kestabilan titik setimbang adanya pemilih golput, akan disubtitusikan titik setimbang adanya pemilih golput $E_{1}$ pada matriks Jacobian (7) sehingga diperoleh: 
$J\left(E_{1}\right)=\left[\begin{array}{ccc}-\frac{\Lambda}{P^{*}} & -\frac{\beta P^{*}}{\left(1+\sigma A^{*}\right)^{2}} & -\eta P^{*} \\ \frac{\beta A^{*}}{1+\sigma A^{*}} & -\frac{\beta \sigma P^{*} A^{*}}{\left(1+\sigma A^{*}\right)^{2}} & 0 \\ \eta R^{*} & \gamma & -\frac{\gamma A^{*}}{R^{*}}\end{array}\right]$.

Selanjutnya, diperoleh persamaan karakteristik sebagai berikut:

$$
\lambda^{3}+p_{1} \lambda^{2}+p_{2} \lambda+p_{3}=0
$$

dengan,

$p_{1}=\left(\frac{\gamma A^{*}}{R^{*}}+\frac{\beta \sigma P^{*} A^{*}}{\left(1+\sigma A^{*}\right)^{2}}+\frac{\Lambda}{P^{*}}\right)$,

$p_{2}=\left(\frac{\Lambda \beta \sigma A^{*}}{\left(1+\sigma A^{*}\right)^{2}}+\frac{\beta^{2} P^{*} A^{*}}{\left(1+\sigma A^{*}\right)^{3}}+\frac{\gamma \beta \sigma P^{*} A^{* 2}}{R\left(1+\sigma A^{*}\right)^{2}}+\frac{\Lambda \gamma A^{*}}{P^{*} R^{*}}+\eta^{2} P^{*} R^{*}\right)$,

$p_{3}=\left(\frac{\Lambda \beta \gamma \sigma A^{* 2}}{R^{*}\left(1+\sigma A^{*}\right)^{2}}+\frac{\beta^{2} \gamma P^{*} A^{* 2}}{R^{*}\left(1+\sigma A^{*}\right)^{2}}+\frac{\beta \eta \gamma P^{*} A^{*}}{1+\sigma A^{*}}+\frac{\beta \sigma \eta^{2} R^{*} P^{* 2} A^{*}}{\left(1+\sigma A^{*}\right)^{2}}\right)$.

Berdasarkan kriteria Routh-Hurwitz, persamaan karakteristik (10) memiliki akar-akar yang memiliki bagian real negatif jika nilai $p_{1}, p_{2}, p_{3}>0$ dan $p_{1} p_{2}-p_{3}>0$. Dari uraian tersebut diperoleh beberapa hal, yaitu

i. Oleh karena semua parameter dan variabel bernilai positif, maka jelas bahwa $p_{1}, p_{2}, p_{3}>0$.

ii. Selanjutnya, titik setimabang $E_{1}$ bersifat stabil asimtotis jika dan hanya jika $p_{1} p_{2}-p_{3}>0$. Karena $p_{1}, p_{2}, p_{3}>0$, maka kondisi tersebut dapat dipenuhi dengan

$$
p_{1} p_{2}>p_{3} \Leftrightarrow \frac{p_{1} p_{2}}{p_{3}}>1 .
$$

Akar-akar dari persamaan (10) sulit untuk ditentukan secara analitik, sehingga titik setimbang adanya pemilih golput ini akan dianalisis melalui simulasi numerik dengan menggunakan bidang fase dengan software MATLAB. Berikut diberikan nilai parameter dan tiga nilai awal pada Tabel 2 dan Tabel 3 untuk masing-masing variabel.

Tabel 2 Nilai parameter pada model matematika partisipasi pemilih pada pemilihan umum dengan saturated incidence rate

\begin{tabular}{ccc}
\hline Parameter & Nilai & Sumber \\
\hline$\Lambda$ & 0.043 & Asumsi \\
$\beta$ & 0.3 & {$[12]$} \\
$\sigma$ & 0.7 & Asumsi \\
$\eta$ & 0.04 & {$[12]$} \\
$\mu$ & 0.04 & {$[12]$} \\
$\gamma$ & 0.08 & {$[12]$} \\
\hline
\end{tabular}


Tabel 3 Nilai Awal Simulasi Bidang Fase

\begin{tabular}{ccccc}
\hline Nilai Awal & $\boldsymbol{P}(\mathbf{0})$ & $\boldsymbol{A}(\mathbf{0})$ & $\boldsymbol{R}(\mathbf{0})$ & Warna \\
\hline Nilai Awal 1 & 100 & 50 & 70 & Hijau \\
Nilai Awal 2 & 80 & 40 & 85 & Biru \\
Nilai Awal 3 & 70 & 55 & 90 & Merah \\
\hline
\end{tabular}

Simulasi ini dilakukan pada waktu $t=0$ sampai $t=1000$. Hasil simulasi bidang fase pada titik setimbang adanya pemilih golput model matematika partisipasi pemilih pada pemilihan umum dengan saturated incidence rate ditunjukkan pada Gambar 2.

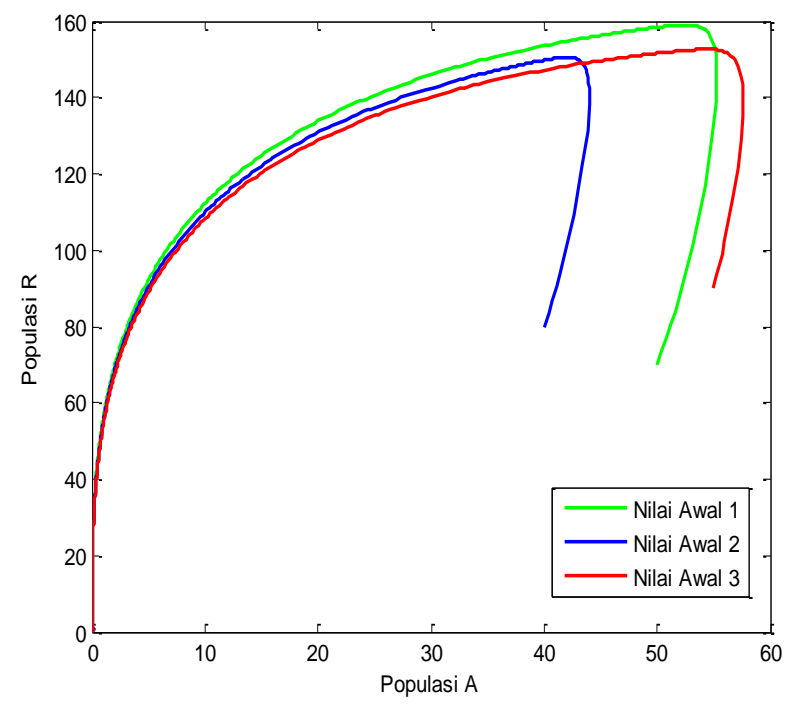

Gambar 2 Bidang Fase untuk Titik Setimbang adanya pemilih golput

Berdasarkan Gambar 2, ketika diberikan tiga nilai awal yang berbeda, grafik populasi $A$ dan $R$ cenderung konvergen ke titik $(A, R)=(0.1394,0.4965)$. Selain itu, berdasarkan nilai parameter pada Tabel 2, diperoleh nilai $R_{0}=2.6875>1$. Hal ini menunjukkan bahwa titik setimbang adanya pemilih golput pada model matematika partisipasi pemilih pada pemilihan umum dengan saturated incidence rate cenderung stabil asimtotis jika $R_{0}>1$.

\section{$4 \quad$ Analisis Sensitivitas Parameter}

Analisis sensitivitas bertujuan untuk mengetahui parameter yang memiliki pengaruh besar pada suatu model [13]. Hal tersebut dapat diketahui melalui indeks sensitivitas dari masing-masing parameter. Adapun indeks sensitivitas parameter (ind $m$ ) dirumuskan sebagai berikut.

$$
\text { ind } m=\left(\frac{\partial R_{0}}{\partial \mathrm{m}}\right) \frac{m}{R_{0}}
$$


dengan $m$ merupakan parameter yang akan dianalisis.

Hasil perhitungan indeks sensitivitas parameter model matematika partisipasi pemilih pada pemilihan umum dengan saturated incidence rate dapat dilihat pada Tabel 4 berikut.

Tabel 4 Nilai indeks sensitivitas parameter

\begin{tabular}{cc}
\hline Parameter & Indeks Sensitivitas \\
\hline$\Lambda$ & 1 \\
$\beta$ & 1 \\
$\gamma$ & -1.333 \\
$\mu$ & -0.666 \\
\hline
\end{tabular}

Selanjutnya, pada Tabel 5 akan ditunjukkan hubungan antara perubahan pada nilai parameter terhadap perubahan $R_{0}$.

Tabel 5 Hubungan antara perubahan pada nilai parameter terhadap nilai $R_{0}$

\begin{tabular}{|c|c|c|c|c|c|}
\hline \multirow{2}{*}{$\begin{array}{l}\text { Parameter } \\
\quad(\boldsymbol{p})\end{array}$} & \multirow{2}{*}{$\begin{array}{c}\text { Indeks } \\
\text { Sensitivitas }\end{array}$} & \multicolumn{4}{|c|}{$R_{0}=2.6875$} \\
\hline & & $p-10 \%$ & $p-15 \%$ & $p+10 \%$ & $p+15 \%$ \\
\hline$\Lambda$ & 1 & 2.42 & 2.28 & 2.96 & 3.09 \\
\hline$\beta$ & 1 & 2.42 & 2.28 & 2.96 & 3.09 \\
\hline$\gamma$ & -1.333 & 2.879 & 2.986 & 2.52 & 2.443 \\
\hline$\mu$ & -0.666 & 3.089 & 3.328 & 2.364 & 2.226 \\
\hline
\end{tabular}

Berdasarkan hasil indeks sensitivitas pada Tabel 5, parameter yang memiliki pengaruh yang besar dalam model matematika partisipasi pemilih pada pemilihan umum dengan saturated incidence rate adalah $\Lambda, \beta$ dan $\gamma$. Namun, karena parameter laju masuk individu baru di dalam sistem pemilu $(\Lambda)$ tidak dapat dikontrol, maka parameter yang berpengaruh adalah parameter $\beta$ dan $\gamma$.

Selanjutnya, akan dilakukan simulasi parameter $\beta$ dan $\gamma$ terhadap $R_{0}$ yang masing-masing merupakan laju individu yang terpengaruh untuk golput dan laju individu yang kehilangan minat untuk golput. Pada simulasi dipilih nilai $\beta=0.03, \beta=0.3$ dan $\beta=3$ dengan $\gamma$ berada pada interval $0.1 \leq \gamma \leq 0.5$. 


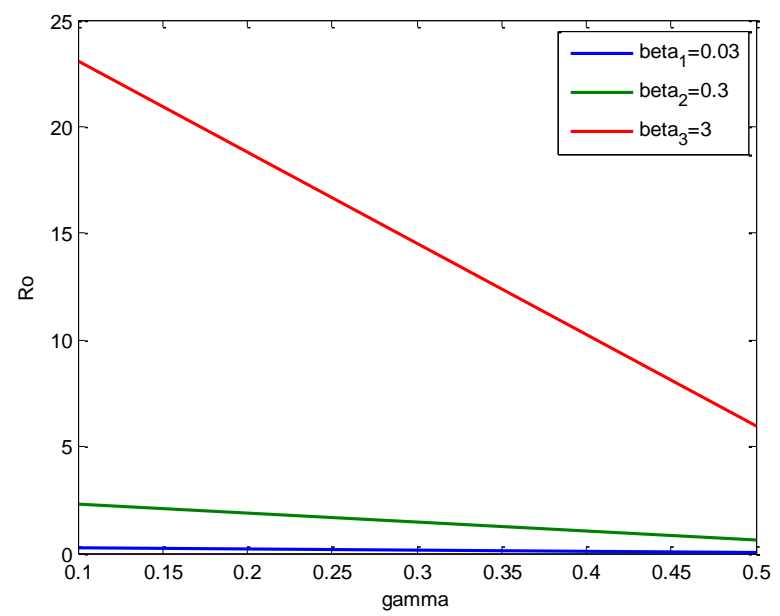

Gambar 3 Sensitivitas terhadap nilai $R_{0}$

Berdasarkan Gambar 3, dapat dilihat bahwa ketika dipilih tiga nilai $\beta$ yang berbeda yaitu $\beta=0.03, \beta=0.3$ dan $\beta=3$ pada interval $0.1 \leq \gamma \leq 0.5$, jika nilai parameter $\gamma$ meningkat, maka nilai $R_{0}$ akan menurun untuk seluruh nilai $\beta$.

\section{Formulasi Model dengan Adanya Kontrol Optimal}

Pada bagian ini akan diformulasikan model matematika partisipasi pemilih pada pemilihan umum dengan saturated incidence rate disertai variabel kontrol. Adapun variabel kontrol yang digunakan berupa kampanye kesadaran $(u)$. Adapun model matematika partisipasi pemilih pada pemilihan umum dengan saturated incidence rate dengan adanya kontrol adalah sebagai berikut.

$$
\begin{aligned}
& \frac{d P}{d t}=\Lambda-\beta \frac{A P}{1+\sigma A}-\eta P R-\mu P, \\
& \frac{d A}{d t}=\beta \frac{A P}{1+\sigma A}-(\gamma+\mu) A-\delta u A, \\
& \frac{d R}{d t}=\eta P R+\gamma A-\mu R+\delta u A .
\end{aligned}
$$

Selanjutnya, fungsi ongkos atau indeks performansi yang dapat dibentuk berdasarkan model matematika partisipasi pemilih pada pemilihan umum dengan saturated incidence rate dengan adanya kontrol berupa kampanye kesadaran adalah sebagai berikut.

$\operatorname{Min} J(u)=\int_{t_{0}}^{t_{f}}\left(a A+\frac{b}{2} u^{2}\right) d t$,

dengan $u \in[0,1]$. 
Indeks performansi ini bertujuan untuk meminimumkan jumlah populasi pemilih yang golput. Input $u$ yang memiliki kisaran nilai $0 \leq u \leq 1$ menunjukkan bahwa kampanye kesadaran memiliki peluang sukses antara 0 sampai 1 , sedangkan $a, b$ secara berturutturut menyatakan konstanta pembobot kepadatan populasi $A$ serta pembobot berupa biaya yang harus dikeluarkan untuk kampanye kesadaran.

\section{Kontrol Optimal}

Permasalahan kontrol optimal pada model matematika partisipasi pemilih pada pemilihan umum dengan saturated incidence rate ini diselesaikan dengan menerapkan Prinsip Maksimum Pontryagin. Misalkan variabel state pada model disertai kontrol optimal sebagai berikut.

$$
x=(P, A, R)^{T},
$$

Dengan nilai awal dari semua populasi diasumsikan non negatif yang dinyatakan sebagai berikut.

$$
P(0), A(0), R(0) \geq 0 \text {. }
$$

Batas waktu pengontrol mempunyai nilai interval $0 \leq t \leq t_{f}$. Hal ini menyatakan waktu pengamatan saat diberi kontrol hingga waktu akhir pengamatan setelah diberi kontrol. Berdasarkan prinsip Maksimum Pontryagin, langkah pertama yang dilakukan adalah membentuk fungsi Hamiltonian pada model sebagai berikut.

$\mathcal{H}=\left[a A+\frac{b}{2} u^{2}\right]+\lambda^{T}(t) f(x(t), u(t))$,

dengan adanya $f(x(t), u(t))$ adalah ruas kanan dari model matematika partisipasi pemilih pada pemilihan umum dengan saturated incidence rate yang disertai variabel kontrol, sedangkan $\lambda(t)$ menyatakan pengali Lagrange atau variabel co-state dengan $\lambda^{T}(t)$ adalah transpos dari $\lambda(t)$. Selanjutnya, agar diperoleh kondisi optimal maka fungsi $\mathrm{H}$ harus memenuhi kondisi stasioner, yaitu

$\frac{\partial \mathcal{H}}{\partial u}=0$

Berdasarkan persamaan (16) diperoleh nilai untuk $u$ dengan $0 \leq u(t) \leq 1$ sebagai berikut. 


$$
u^{*}=\left\{\begin{array}{c}
0 \\
\frac{1}{b}\left[\delta A\left(\lambda_{2}-\lambda_{3}\right)\right] \\
1
\end{array}\right.
$$

$$
\begin{gathered}
\text { untuk } u \leq 0 \\
\text { untuk } 0<u<1 \\
\text { untuk } u \geq 1
\end{gathered}
$$

Dari sini, diperoleh nilai kontrol yang optimal adalah sebagai berikut.

$$
u^{*}=\min \left(1, \max \left(0, \frac{1}{b}\left[\delta A\left(\lambda_{2}-\lambda_{3}\right)\right]\right)\right)
$$

Selanjutnya, karena dalam pengontrol $u^{*}$ terdapat variabel state yaitu $x=(P, A, R)^{T}$, dengan demikian akan ditentukan penyelesaian persamaan state untuk memperoleh variabel tersebut yaitu

$$
\dot{x}=\frac{\partial x}{\partial \lambda}
$$

Berikutnya, persamaan co-state pada pengontrol $u^{*}$ dapat diperoleh dari

$$
\dot{\lambda}=-\frac{\partial H}{\partial x},
$$

Dengan demikian diperoleh,

$$
\begin{aligned}
\dot{\lambda}_{1}=-\frac{\partial H}{\partial P}=- & {\left[\lambda_{1}\left(-\frac{\beta A}{1+\sigma A}-\eta R-\mu\right)+\lambda_{2}\left(\frac{\beta A}{1+\sigma A}\right)+\lambda_{3}(\eta R)\right], } \\
\dot{\lambda}_{2}=-\frac{\partial H}{\partial A}=- & {\left[a+\lambda_{1}\left(\frac{\beta P}{1+\sigma A}-\frac{\beta P \sigma A}{(1+\sigma A)^{2}}\right)\right.} \\
& \left.+\lambda_{2}\left(\frac{\beta P}{1+\sigma A}-\frac{\beta P \sigma A}{(1+\sigma A)^{2}}-(\gamma+\mu)-\delta u\right)+\lambda_{3}(\gamma+\delta u)\right], \\
\dot{\lambda}_{3}=-\frac{\partial H}{\partial R}= & -\left[\lambda_{1} \eta P+\lambda_{3}(\eta P-\mu)\right] .
\end{aligned}
$$

dengan $\lambda_{i}\left(t_{f}\right)=0$, untuk $\mathrm{I}=1,2,3$.

Selanjutnya, setelah didapatkan variabel state dan co-state, maka nilai tersebut akan disubstitusikan ke $u^{*}$. Solusi yang optimal diperoleh dengan mensubstitusikan strategi pengendali $u^{*}$ ke dalam persamaan state. Kemudian, untuk memperoleh nilai $P, A, R$ dari bentuk $u^{*}$ yang optimal maka harus ditentukan penyelesaian persamaan state yang berbentuk non linier dan sulit untuk diselesaikan secara analitik sehingga akan diselesaikan secara numerik. 


\section{$7 \quad$ Simulasi Numerik}

Simulasi ini digunakan untuk mengetahui efektivitas dari adanya kontrol $u$ yaitu berupa kampanye kesadaran. Adapun nilai awal yang digunakan pada simulasi ini adalah $\left(P\left(t_{0}\right), A\left(t_{0}\right), R\left(t_{0}\right)\right)=(1009080)$. Waktu awal dan akhir pengamatan pada simulasi ini berturut-turut adalah $t_{0}=0$ dan $t_{f}=50$ dalam satuan bulan. Konstanta pembobot untuk populasi yang golput sebesar $a=1$. Selanjutnya, konstanta pembobot untuk biaya usaha kampanye kesadaran (b) sebesar 10. Adapun nilai parameter yang digunakan mengacu pada Tabel 2 dengan $\Lambda=5$. Pada program ini, persamaan state didefinisikan sebagai $P=y(1), A=y(2)$, dan $R=y(3)$. Selain itu, indeks performansi didefinisikan sebagai state baru yaitu $y(4)$, serta pengendali $u$. Hasil simulasi numerik kontrol optimal partisipasi pemilih pada pemilihan umum dengan saturated incidence rate disajikan pada Gambar 4.

Berdasarkan Gambar 4, diperoleh perbandingan populasi sebelum dan sesudah diberi kontrol dengan dua skenario untuk populasi pemilih yang golput (a) dan populasi pemilih yang terdaftar dan menggunakan hak pilih (b). Perbandingan jumlah populasi dapat dilihat pada Tabel 6.

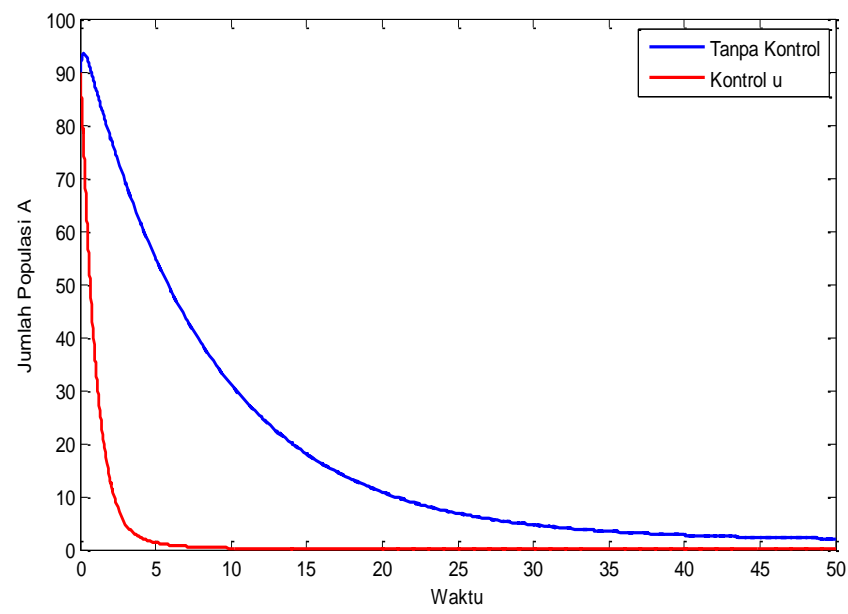

(a) Grafik Populasi A 


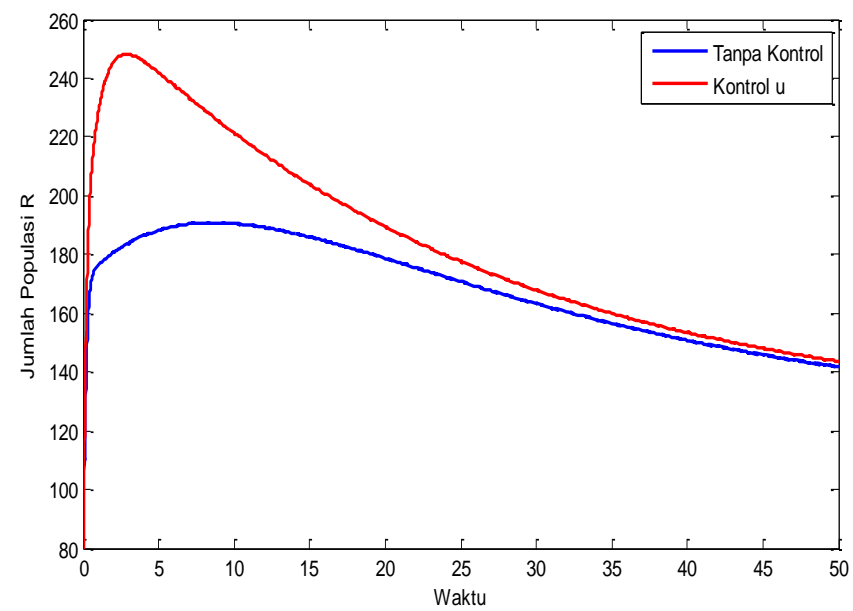

(b) Grafik Populasi R

Gambar 4 Simulasi perbandingan jumlah populasi $A$ dan $R$.

Tabel 6 Perbandingan populasi $A$ dan $R$ pada waktu akhir pengamatan

\begin{tabular}{lcc}
\hline \multirow{2}{*}{ Kondisi } & Jumlah Populasi \\
& $\boldsymbol{A}$ & $\boldsymbol{R}$ \\
\hline Tanpa Kontrol & 2 & 141 \\
Dengan Kontrol $u$ & 0 & 143 \\
\hline
\end{tabular}

Berdasarkan Tabel 6, secara umum terlihat adanya perbedaan jumlah populasi tanpa kontrol dan ketika diberikan kontrol dengan dua skenario. Populasi pemilih yang golput (A) mencapai jumlah penurunan populasi terkecil pada akhir waktu dengan pemberian kontrol upaya kampanye kesadaran. Berikutnya, populasi pemilih yang terdaftar dan menggunakan hak pilih $(R)$ pada awal waktu pemberian kontrol $u$ berupa kampanye kesadaran memiliki pengaruh yang sangat besar dalam meningkatkan jumlah populasi. Seiring dengan bertambahnya waktu, efektivitas kontrol berkurang karena adanya pengaruh dari faktor teknis selama pengadaan pemilihan umum. Faktor tersebut antara lain pemilih lebih mengutamakan urusan pribadi yang mendesak seperti sedang bekerja atau sakit serta kesulitan dalam sistem administratif pemilihan umum.

Selanjutnya, hasil simulasi numerik untuk profil usaha $u$ disajikan pada Gambar 5. 


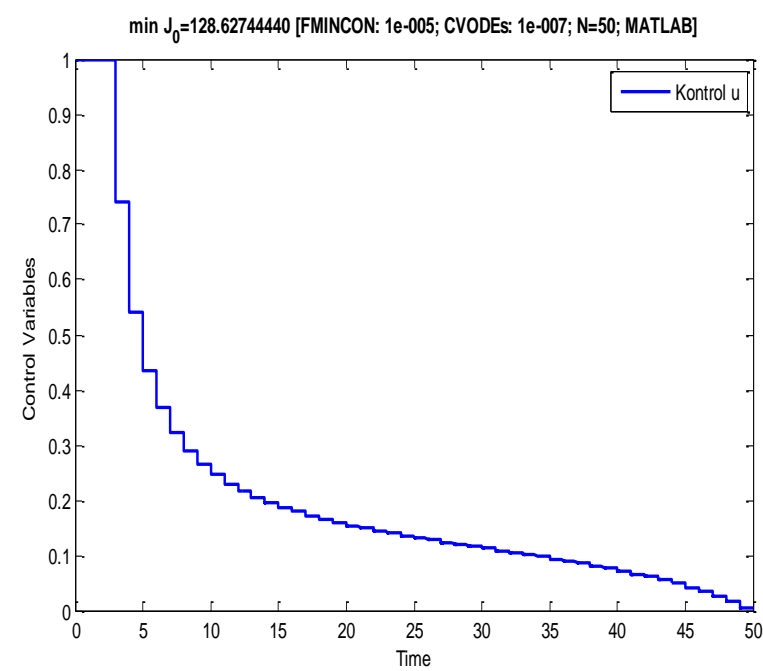

Gambar 5 Grafik Profil Usaha $u$

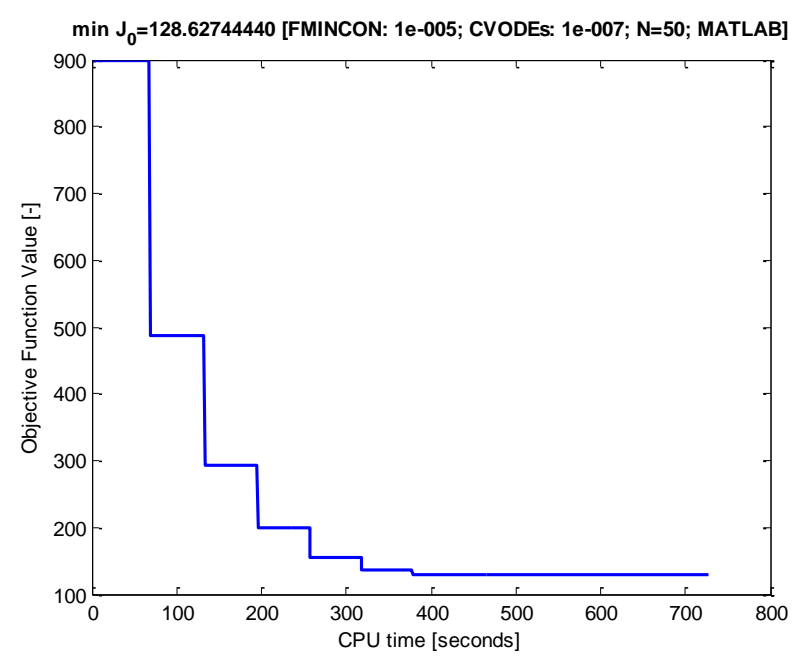

Gambar 6 Grafik Fungsi Ongkos

Adapun fungsi ongkos kontrol $u$ adalah sebesar 128.627 guna meminimalkan jumlah populasi pemilih yang golput dengan pemberian kontrol berupa kampanye kesadaran. Dengan demikian dari pemaparan diatas dapat disimpulkan bahwa untuk meminimalkan jumlah populasi pemilih yang golput serta meminimalkan biaya, maka langkah yang efektif dengan menerapkan kontrol $u$ berupa kampanye kesadaran.

\section{Kesimpulan}

Berdasarkan pembahasan yang telah diuraikan sebelumnya, maka dapat ditarik kesimpulan sebagai berikut: 
1. Model matematika partisipasi pemilih pada pemilihan umum dengan saturated incidence rate memiliki dua titik setimbang yaitu titik setimbang non pemilih golput $\left(E_{0}\right)$ dan titik setimbang adanya pemilih golput $\left(E_{1}\right)$. Titik setimbang non pemilih golput akan stabil asimtotis jika memenuhi $R_{0}<1$. Titik setimbang adanya pemilih golput cenderung stabil asimtotis jika memenuhi $R_{0}>1$, dengan

$$
R_{0}=\frac{\beta \Lambda}{(\gamma+\mu) \mu} \text {. }
$$

2. Bentuk fungsi kontrol optimal model matematika partisipasi pemilih pada pemilihan umum dengan saturated incidence rate adalah sebagai berikut.

$u^{*}=\min \left(1, \max \left(0, \frac{1}{b}\left[\delta A\left(\lambda_{2}-\lambda_{3}\right)\right]\right)\right)$.

3. Berdasarkan hasil simulasi numerik pada model matematika partisipasi pemilih pada pemilihan umum dengan saturated incidence rate sebelum dan sesudah diberi kontrol menunjukkan bahwa pemberian kontrol berupa kampanye kesadaran $u$ merupakan langkah yang optimal dalam menurunkan jumlah populasi pemilih yang golput.

\section{Daftar Pustaka}

[1] Liando, D. M., 2017, Pemilu dan Partisipasi Politik Masyarakat (Studi Pada Pemilihan Anggota Legislatif Dan Pemilihan Presiden Dan Calon Wakil Presiden Di Kabupaten Minahasa Tahun 2014), Jurnal LPPM Bidang EkoSosBudKum, 3(2), 14-28.

[2] Surbakti, A. R., Supriyanto, D., dan Santoso, T., 2008, Perekayasaan sistem pemilu untuk pembangunan tata politik demokratis, Partnership for Governance Reform Indonesia.

[3] R.I., Undang-Undang Nomor.7 Tahun 2017 tentang "Pemilihan Umum"

[4] Surbakti, R., 1992, Memahami ilmu politik, Jakarta: PT Grasindo.

[5] Budiarjo, Miriam., 2008, Dasar-Dasar Ilmu Politik. Jakarta:PT Gramedia Pustaka Utama.

[6] Surbakti, Ramlan., 1999, Memahami Ilmu Politik, Cetakan keempat, Jakarta: Grasindo.

[7] Petersen, I., 1991, Stability of equilibria in multi-party political systems, Mathematical Social Sciences, vol.21, no.1, pp.81-93.

[8] Ansolabehere, S., 2005, The Introduction of Voter Registration and Its Effect on Turnout, Political Analysis, vol.14, no.1, pp.83-100.

[9] Yong, B., dan Samat, N, A., 2018, The SIR political fanaticism figure voters model for estimating number of voter in Indonesian presidential elections, Model Assisted Statistics and Applications, 13(3), 279-286.

[10] Calderon, K., Orbe, C., Panjwani, A., Romero, D, M., Kribs-Zaleta, C., dan RosSoto, K., 2005, An Epidemiological Approach to the Spread of Political Third Parties, Arizona State University, Tempe, AZ, USA. 
[11] Balatif, O., Labzai, A., dan Rachik, M., 2018, A Discrete Mathematical Modeling and Optimal Control of the Electoral Behavior with Regard to a Political Party, Discrete Dynamics in Nature and Society Research Article, vol.2018, Article ID 9649014, 14 pages.

[12] Balatif, O., Khajji, B., dan Rachik, M., 2020, Mathematical Modeling, Analysis, and Optimal Control of Abstinence Behavior of Registration on the Electoral Lists, Discrete Dynamics in Nature and Society Research Article, vol.2020, Article ID 9738934, 12 pages.

[13] Chitnis, N., Hyman, J. M., dan Cushing, 2008, Determine Important Parameters in the Spread of Malaria Through the Sensitivity Analysis of a Mathematics Model, Bulletion of Mathematical Biology, 70, 1272 - 1296. 